\title{
Overview on Epigenetics and Cancer
}

\section{Eman Refaat Youness}

Department of Medical Biochemistry, National Research Centre, Egypt

Corresponding Author Eman Refaat Youness, Department of Medical Biochemistry, National Research Centre, Egypt

Received date: February 19, 2020; Accepted date: February 27, 2020; Published date: March 11, 2020.

Citation: Eman R Youness (2020) Overview on Epigenetics and Cancer, 2(3): DOI: 10.31579/ 2690-8794/015

Copyright: () 2020 Eman Refaat Youness, This is an open-access article distributed under the terms of The Creative Commons Attribution License, which permits unrestricted use, distribution, and reproduction in any medium, provided the original author and source are credited.

\begin{abstract}
Epigenetics is considered as the science of hereditary phenotype which does not encompass amendment in the DNA. This occurs through chemical processes that modify the phenotype, without altering the genotype. A large number of studies showed that metabolic diseases are highly associated with epigenetic alterations suggesting that epigenetic factors may play a central role in cancer. Recent advancements in the rapidly evolving field of cancer epigenetics have shown extensive reprogramming of every component of the epigenetic machinery in cancer including DNA methylation, histone modifications, nucleosome positioning and noncoding RNAs, specifically microRNA expression. Studies of the mechanism(s) of epigenetic regulation and its reversibility have resulted in the identification of novel targets that may be useful in developing new strategies for the prevention and treatment of cancer.
\end{abstract}

Keywords: epigenetics; cancer; hereditary phenotype; metabolic diseases

\section{Introduction}

Epigenetics is considered as the science of hereditary phenotype which do not encompass amendment in the DNA [15]. This occurs through chemical processes that modify the phenotype, without altering the genotype [18]. In epigenetics, the Greek acanthus epi-(over) behold countenance which is "on the top of" i.e "in addition to" the conventional basis of inheritance of genetic [49]. Epigenetics frequently betoken changes that affect gene expression and activity. Also, it is used to depict each change in the heritable phenotype. Any effect in the physiological \& cellular phenotypic traits could arise by environmental and external factors [6].

This means pertinent changes to the genome but not involve an alteration in the sequence of nucleotide. Expression of genes could be well-ordered via the repressor proteins which bind to silence regions in DNA. These alterations possibly will remain over cell divisions for the period of the cell's life. It could also continue in multiple generations while they include no variations in the sequence of DNA of the organism [7].

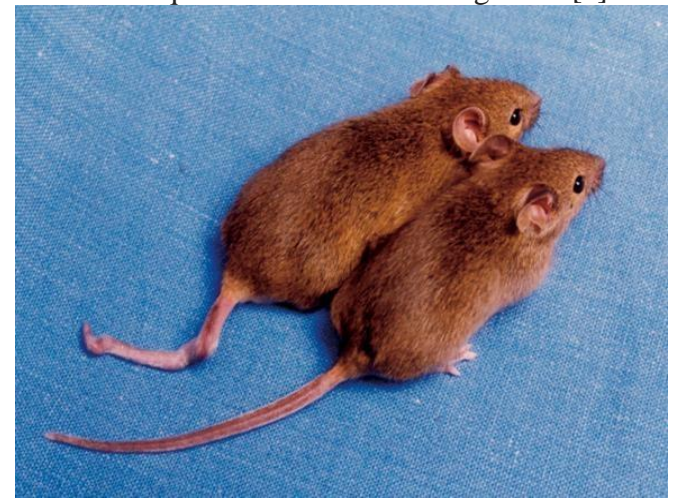

Figure (1): Different Kink in the Tail but Same Genes
Epigenetic alterations amend definite genes activation, not the genetic code DNA sequence. The structure of DNA or the related chromatin proteins may be adjusted, producing either silencing or activation. This mechanization allows cells to make the genes that are essential for their own activity only. Epigenetic alterations conserved during cell division. The majority of epigenetic alterations occur only within lifetime of the organism. These alterations could be patrimonial to progeny via a process termed trans-generational epigenetic inheritance. Additionally, whether gene inactivation occurs in an egg or sperm which leads to fertilization, this epigenetic modification could be transmitted to the following offspring [8].

\section{Epigenetic Phenomena}

Epigenetics and development continue from solitary impregnated embryo into immeasurable various tissues and cells [39]. It was notable that more modern and accurate epigenetic concept could be observed early in variegating eye colour in Drosophila which changes from generation to another [29]. In yeast, the effect of telomere location found like the idea of semen as it switches among phenotypes happens with no genotypic variation [19]. Epigenetics still in its infancy, by the persistent appearance of new states (bivalent promoters), novel players (lncRNAs) and novel histonemodification [39].

DNA is compacted in chromatin and nucleosome is its basic unit. Each nucleosome is formed of histone. This histone surrounded by about 145-147 DNA base pairing. Histone designed as four proteins couples, named H2A, H2B, H3, and H4. DNA is firstly "supercoiled" and then wrapped onto histones, to allow their compressing into a single cell [33].There are two types of chromatins rendering to the grade of winding of DNA. DNA in euchromatin, is extra relaxed allowing genes transcription, \& DNA in heterochromatin is super-coiled and cannot accessed for gene transcription (Fig.2). 


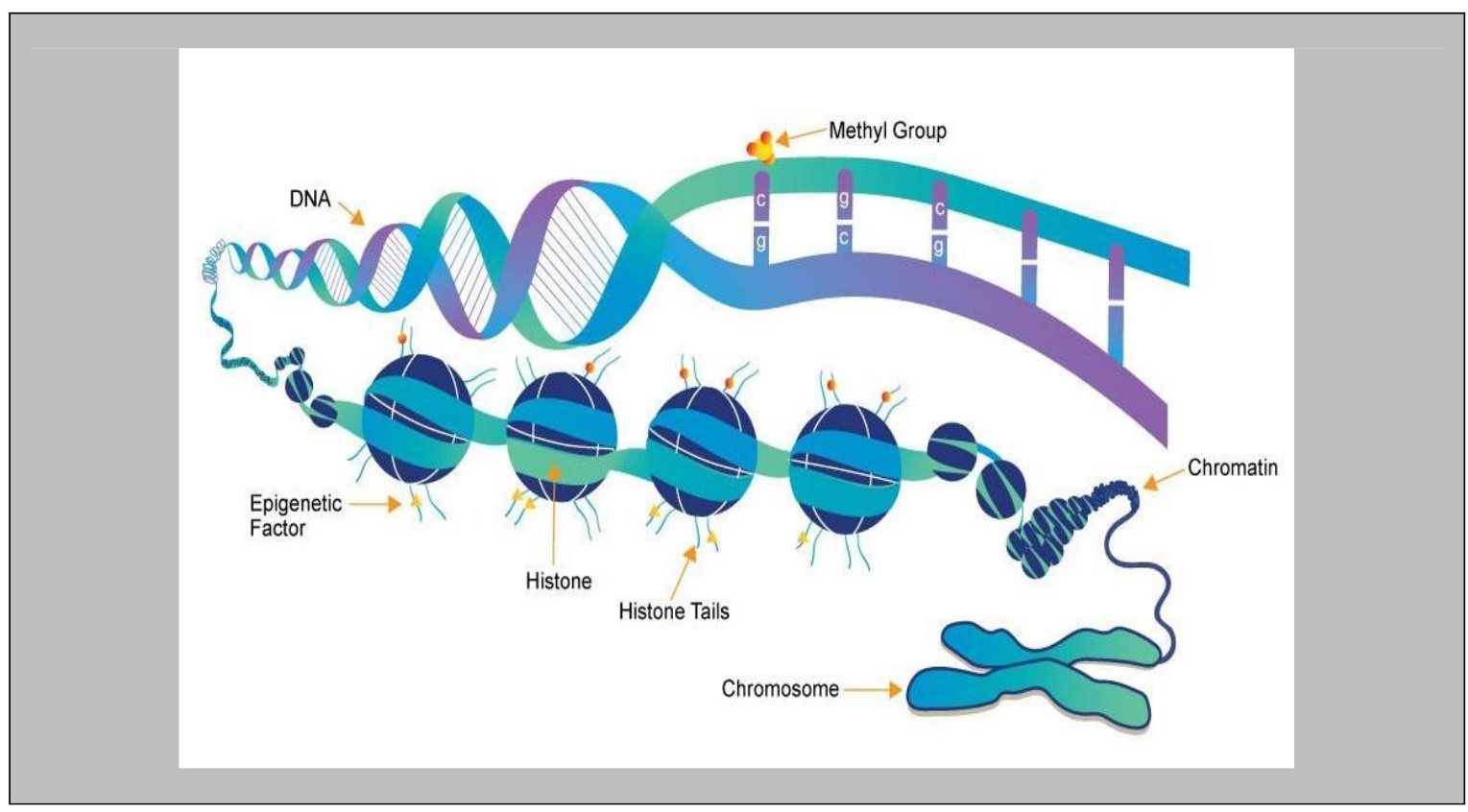

Figure (2): Chromatin structure representation, including DNA and histones, which become ready for epigenetic marks.

There is equilibrium between euchromatin \& heterochromatin that authorize the cells to amend gene expression. This leads to notable alterations in their biological and functions phenotypes [58]. This merit achieves from the same DNA sequence; cells might discriminate in actual dissimilar means. The renovation between euchromatin and heterochromatin is called epigenetic regulation [43].Sequence; cells might discriminate in actual dissimilar means. The renovation between euchromatin and heterochromatin is called epigenetic regulation [43].

\section{The Major Epigenetic Mechanisms}

\section{DNA methylation}

Methylation of DNA is firmly concomitant with parental imprinting, circumstantial regulation of gene expression and time, silencing of repetitive elements, inactivation of $\mathrm{X}$-chromosome, human diseasesand cell differentiation (Tirado-Magallanes et al., 2017). Chemical process in the methylation of DNA, a $\mathrm{CH}_{3}$ group is linked together with cytosine residue at $\mathrm{C}_{5}$, producing 5-methylcytosine (5mC) (Fig.3).

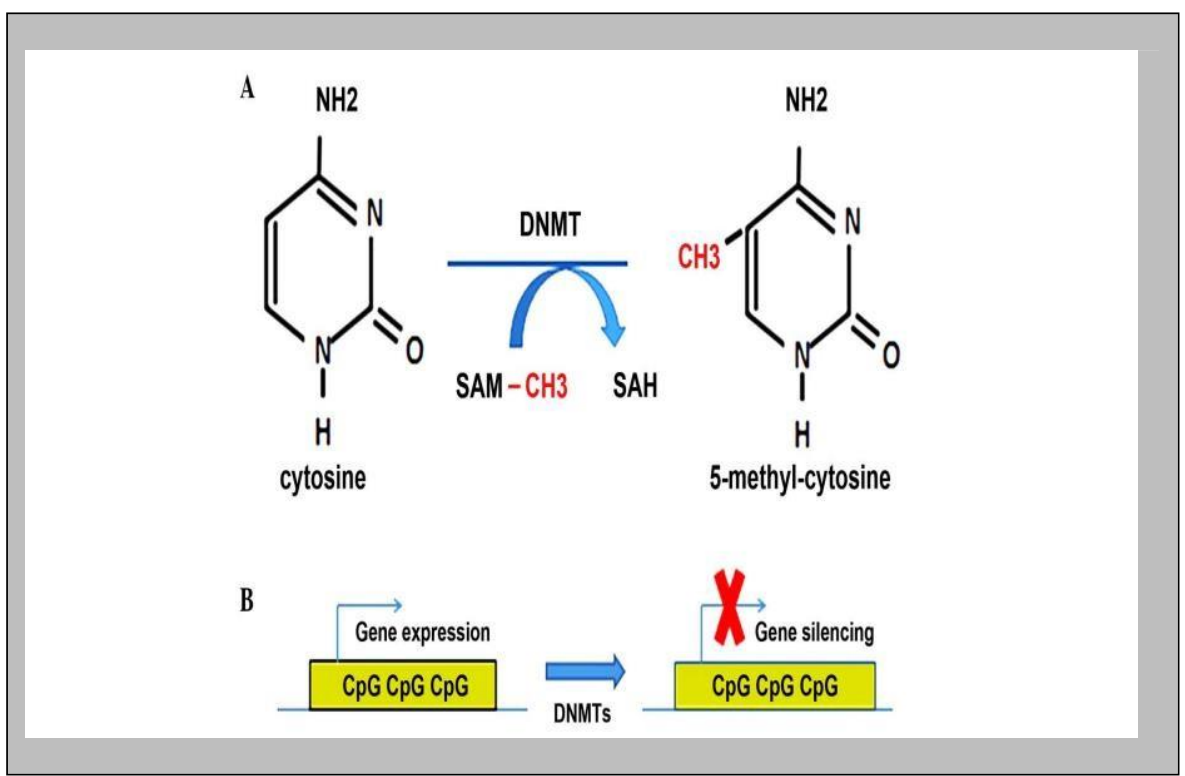

Figure (3): DNA methylation

Methylation of DNA is implement by DNA methyltranferase (DNMTs) certain sequences in DNA specially rich in guanine \& cytosine nucleotide pairs, termed $\mathrm{CpG}$ areas, are the idealgoal of DNMTs. CpG regions in DNA of humans, $\left(5^{\prime}-\mathrm{C}-\right.$ phosphate $\left.-\mathrm{G}-3^{\prime}\right)$ are not distributed at random. They are focused in small enriched CpG DNA morsels, termed $\mathrm{CpG}$ islands. Around $60 \%$ of all promoters in genes are wealthy of $\mathrm{CpG}$ islands, so these genes can be regulated epigenetically. There are 2 types of DNMT. DNMT1, which conserves predating 
manner of methylation next DNA replication in the cells, DNMT3A \& DNMT3B, called "de novo" DNMT, that methylate earlier unmethylated DNA [43].

Demethylation of DNA could be passive, a method emerging due to DNA replication deprived of de novo methylation coupling, or active; this including the interposes 5-formylcytosine (5fC), 5- hydroxymethylcytosine (5hmC), also, 5-carboxycytosine (5caC) [47]. The active demethylation be contingent on protein complexes (demethylase) as base-excision repair (BER) and thymine DNA glycosylase (TDG) [26].

General patterns for DNA methylation that manipulate the gene expression regulation are abridged herein fig. (4) [24].

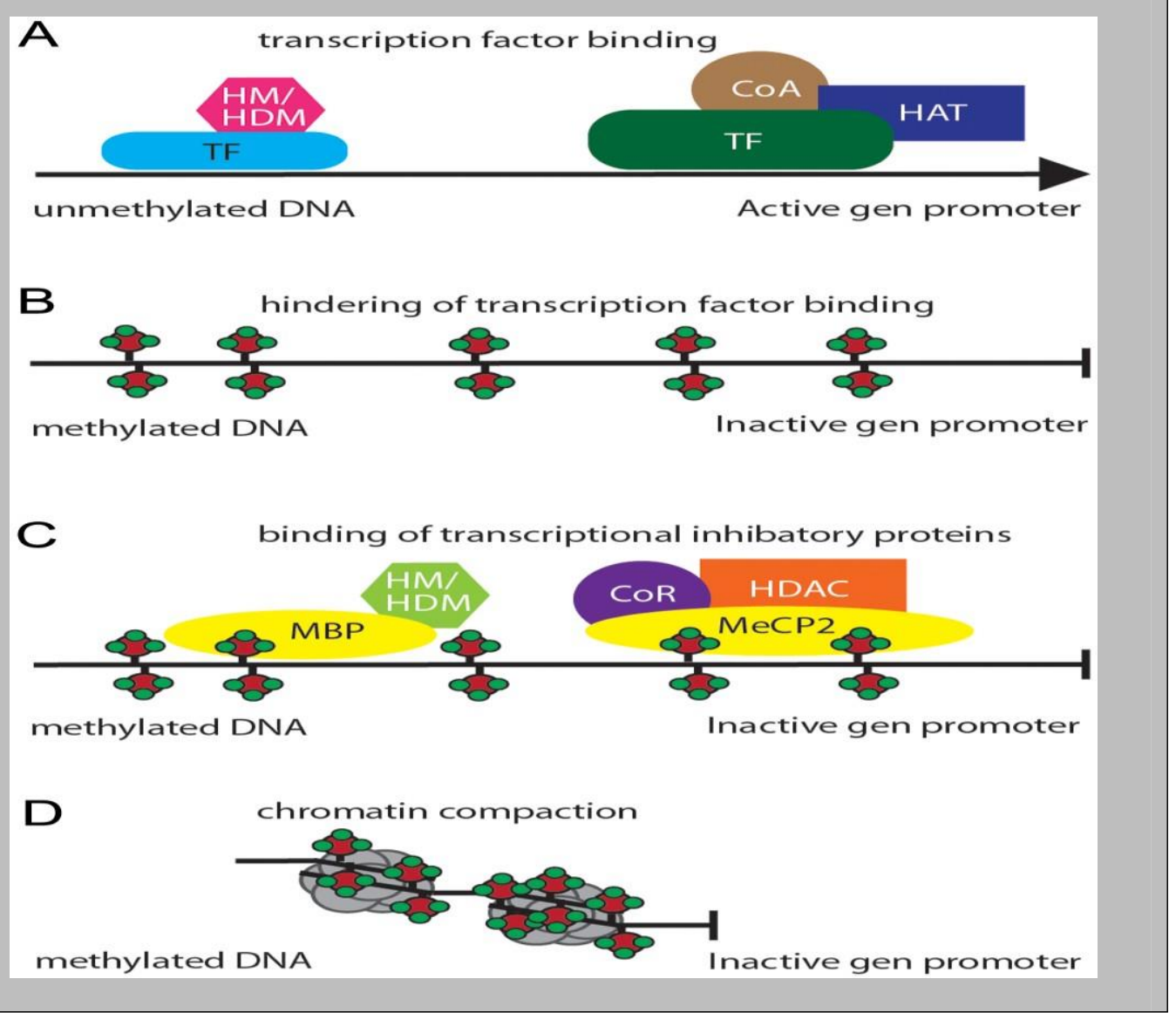

Figure (4): Mechanisms of transcriptional regulation during promoter methylation of DNA. (A): a promoter that is transcriptionally active, (TFs) transcription factors cause open chromatin by means of relative nucleosome lessening \& transcriptional (CoA)co-activator presence. The conclusion was reached during protein complexes by way of e.g. histone methylation (HM), histone acetylase (HAT), and histone demethylation (HDM) activities. (B):After methylation of promoter of DNA, binding of transcription factors is prohibited by plugged of the distinct recognition of sequences. This cause diminished activity of the promoter. (C): After DNA promoter methylation, $5 \mathrm{mC}$ induct methyl-CpG binding protein 2 (MeCP2) \& members of the methyl-CpG binding protein (MBP). These proteins are able toplay a role in mediating transcriptional repressionof protein complexes. This depends on histone HM, (HDAC) deacetylase, \& HDM activities on the way to histone tail residues, and induct transcriptional co-repressors (CoR). (D): Chromatin remodeling and compaction leads to an oppressive transcriptional context.

Genes that transcribed actively are generally conspicuous hypomethylation around the transcription start point. The intricacy of the link between methylation and DNA transcription was demonstrated through genes together with promoters possessing decreased content of $\mathrm{CpG}$ region and hypermethylation that transcriptionally active; e.g., in gamete formation [21]. Furthermore, genes that are transcriptionally active are usually hypermethylated in the gene of the body [4]. This is supposed to chunk the start of false transcription, promote production of abnormal RNAs [40].

Human being genome comprises about fifty six million sites for $\mathrm{CpG}$, about $65-75 \%$ of them be methylated [28]. During genome, sites of CpG are distributed unequally. $\mathrm{CpG}$ islands are demarcated as zones with minimum size, 550 b.p [12]. During the mammalian life cycle, epigenetic marks endure wide reprogramming and methylation of the $\mathrm{CpG}$ site, both are developmentally planned and gained environmentally. They reprogrammed in general after fertilization throughout early gametogenesis and in the zygote proximately[55]. Reprogramming includes wiping off of most DNA methylation that followed by the formation of newgroups of marks of DNA methylation [37]. The wiping off of DNA methylation throughout reprogramming was wide-ranging however, some DNA methylation continues and smooth the way for potential epigenetic inheritance [59].

\section{DNA Hydroxymethylation}

Hydroxymethylation of Cytosine was concealed as another significant epigenetic modification of DNA in mammals. Like 
methylation, hydroxymethyl group replaces the hydrogen atom at the cytosine position-C5, (fig 5).

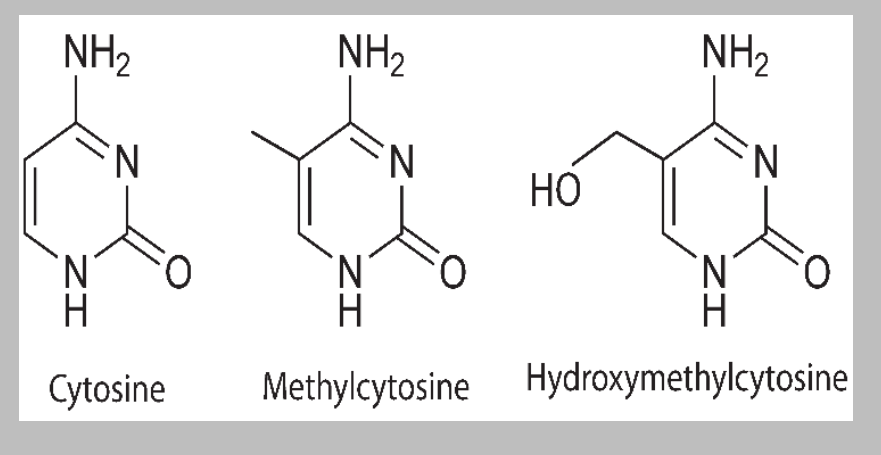

Figure (5): Comparison of cytosine, methylcytosine and hydroxymethylcytosine

It has been elucidated that hydroxymethylation of cytosine is involved also in gene regulation. e.g., the hydroxymethylation level was linked with the stem cells pluripotency. Disturbing of DNA cytosine hydroxymethylation could lead to jumbled cell functions; give rise to altered species of cancers, such as cancers of myeloid [45].

\section{Histone and DNA}

Proteins termed histones are that relate the DNA in chromosomes in eukaryotes forming basic units named nucleosomes. The DNA double helix is swathed around histones. Then these nucleosomes packed together to form chromatin. Chromatin appears as visible stainable mass under microscope during cell division. This chromatin comprises the chromosome bounded by non-histone and histone proteins [1](Fig 6).

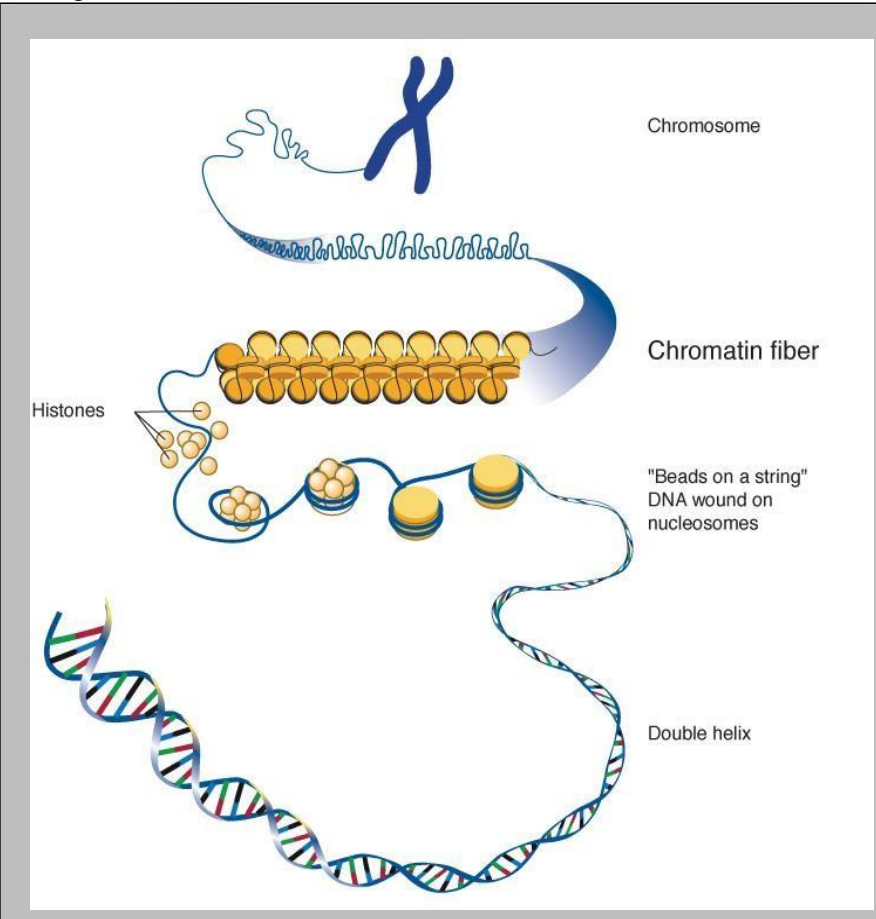

Figure(6): Nucleosomes help package the DNA in a compact form that fits in the nucleus of the cell
In mammals, all chromatin structure can be inherited is a form of epigenetic inheritance since it does not require the direct modification of DNA. The highly condensed form of chromatin, heterochromatin, can switch off any genes in this way. This type of chromatin can be effective as an epigenetic mechanism, as the DNA is stiffer to access to be transcribed. In the other type of chromatin, euchromatin, there is an open chromatin and the genes are ready to be accessed. It was found that genes in heterochromatin are commonly silenced and active in euchromatin [36].

Just as DNA is methylated, histones may also be modified, by methylation, phosphorylation, acetylation, ADP ribosylation and proline isomerization, but these methods of histone modification have not all presented an obvious epigenetic effect similar to DNA methylation [52].

\section{Histone modifications}

Histone covalent modifications play an imperative role in epigenetic regulation. This occurs though binding of different enzymes to histones causing phosphorylation, acetylation, methylation, or ubiquitylation to them. These modulations result in gene transcription \& chromatin relaxation. On the other side, chromatin compaction \& gene repression occur. Whereas DNA methylation cause silence to histone modifications, gene expression, are capable for activation or silencing of genes. This depends on adding residues on the beleaguered histones, finally on the degree of the modulation [55]. E.g., lysine acetylation at the $\mathrm{N}$-terminal of histone is capable to eradicate the histones positive charge, allowing negatively charged DNA to be detached from them and gaina transcription-ready arrangement. Furthermore, methylation of histonelysine leads to transcriptional activation or suppression. This depends on the position of methylated lysine. Acetylation of histones is interposed by (HAT) histone acetyltransferase, whereas deacetylations are encouraged by (HDAC) histone deacetylases. In acetylation and methylation, the preferred targets are the $\mathrm{H} 3$ and $\mathrm{H} 4$ center histones the same as the enormous preponderance of covalent modifications include them. In general, H4K20 methylation, H3K27 and histone H3K9 (lysine in position 9 ofthe $\mathrm{H} 3$ histone), are related with repression of gene. Conversely, methylation of $\mathrm{H} 3 \mathrm{~K} 36$ \& $\mathrm{H} 3 \mathrm{~K} 4$, also, acetylation of $\mathrm{H} 4$ $\& \mathrm{H} 3$, categorizes zones of active gene expression [33].

\section{Regulation of miRNA}

Mi- RNAs (mi-RNAs) are short non-coding RNAs (18-20 nucleotides), that join messenger RNA (mRNAs) through complete or incomplete matching their 3' untranslated zones and resulting in their deprivation and post-transcriptional gene silencing. Various mi-RNAs positions are situated in the intron regions. Mi-RNAs are capable to permit epigenetic control on apoptosis, and other fateful biological processes [14].

\section{Abnormalities of epigenetic in tumorigenesis}

Mechanisms of epigenetics are in demanded for preserving normal development, growth \& expression of genes in various organs. Abnormality of epigenetic regulation may change the expression of genes and functions which could result in diseases as cancer. During formation of cancer, a large number of mutated genes are produced or abnormally activated [9]. (Fig.7).

There is equilibrium between euchromatin \& heterochromatin that authorize the cells to amend gene expression. This leads to notable alterations in their biological and functions phenotypes [58]. This merit achieves from the same DNA sequence; cells might discriminate in actual dissimilar means. The renovation between euchromatin and heterochromatin is called epigenetic regulation (Perria et al. 2017). 


\section{References}

1. Alberts, Br, Alexander J, Julian L, Martin R, Keith R, et al (2008): Molecular biology of the cell. New York: Garland Science,. Print.

2. Andrews L, Andersen R.F, Webster D, Dunachie S, Walther R.M, Bejon P, et al (2005): Quantitative real-time polymerase chain reaction for malaria diagnosis and its use in malaria vaccine clinical trials. The American Journal of Tropical Medicine and Hygiene 73, 191-198.

3. Ara A.I, Xia M, Ramani K, Mato J.M, Lu S.C., (2008):Sadenosyl methionine inhibits lipopolysaccharide-induced gene expression via modulation of histone methylation. Hepatology;47:1655-66.

4. Ball M.P, Li J.B, Gao Y, Lee J.H, LeProust E.M, et al (2009): Targeted and genome-scale strategies reveal gene-body methylation signatures in human cells. Nature Biotechnology 27 361-368.

5. Barski A, Cuddapah S, Cui , Roh T.Y, et al (2007): Highresolution profiling of histone methylations in the human genome. Cell 129: 823-837.

6. Berger S.L, Kouzarides T, Shiekhattar R, Shilatifard A. (2009): "An operational definition of epigenetics". Genes \& Development. 23 (7): 781-83.

7. Bird A.(2007):"Perceptions of epigenetics".Nature.447(7143): 396-98.Bibcode:2007Natur.447.396B.

8. Chandler V.L. (2007):"Paramutation from maize to mice". Cell. 128 (4): 641-45.

9. Chen Q.W, Zhu X.Y, Li Y.Y. and Meng Z.Q. (2014): Epigenetic regulation and cancer. Oncology Reports 31: 523532.

10. Cho B, Lee H, Jeong S, Bang YJ, Lee HJ, et al (2003): Promoter hypomethylation of a novel cancer/testis antigen gene CAGE is correlated with its aberrant expression and is seen in premalignant stage of gastric carcinoma. Biochem Biophys Res Commun 307: 52-63.

11. Dammann R, Schagdarsurengin U, Liu L. Otto N, Gimm O, Dralle H., Boehm B.O, et al Frequent RASSF1A promoter hypermethylation and K-ras mutations in pancreatic carcinoma. Oncogene 22: 3806-3812.

12. Deaton A.M. and Bird A. (2011): $\mathrm{CpG}$ islands and the regulation of transcription. Genes and Development 251010 1022.

13. Dekker J. and L. Mirny (2016): The 3D genome as moderator of chromosomal communication. Cell. 164,1110-1121.

14. Della V. G, Calura E, Di Marino M, Romualdi C, Beltrame L, (2014) et al Analysis of differential miRNA expression in primary tumor and stroma of colorectal cancer patients. Biomed.Res. Int., 840921.

15. Dupont C, Armant D.R, Brenner C.A. (2009): "Epigenetics: definition, mechanisms and clinical perspective". Seminars in Reproductive Medicine. 27 (5): 351-57.

16. Fang J.Y, Lu R, Mikovits J.A, Cheng Z.H, Zhu H.Y (2006) et al Regulation of hMSH2 and hMLH1 expression in the human colon cancer cell line SW1116 by DNA methyltransferase 1. Cancer Lett 233: 124-130.

17. Feng Y, Wang X, Xu L, Pan H, Zhu S, (2009) et al The transcription factor ZBP-89 suppresses p16 expression through a histone modification mechanism to affect cell senescence. FEBS J 276: 4197-4206.

18. Gökbuget D and Blelloch R. (2019): Epigenetic control of transcriptional regulation in pluripotency and early differentiation. Development. 146.
Gottschling D. E, Aparicio O. M, Billington B. L, and Zakian V. A. (1990): Position effect at S. cerevisiae telomeres: reversible repressionof Pol II transcription. Cell 63: 751-762.

20. Gottschling, D. E, O. M. Aparicio, B. L. Billington, and V. A. Zakian, (1990): Position effect at S. cerevisiae telomeres: reversible repression of Pol II transcription. Cell 63: 751-762.

21. Hammoud S.S, Nix D.A, Zhang H, Purwar J, Carrell D.T, (2009) et al Distinctive chromatin in human sperm packages genes for embryo development. Nature $460473-478$.

22. Henrique R, Costa V.L, Cerveira N,Carvalho A.L, Hoque M.O, et al (2006): Hypermethylation of Cyclin D2 is associated with loss of mRNA expression and tumor development in prostate cancer. J Mol Med 84: 911-918.

23. HollidayR.(1990):"DNAMethylation and Epigenetic Inheritance".Philosophical Transactions of the Royal Society of London. Series B, Biological Sciences. 326(1235): 329-338.

24. Jones P.A. (2012): Functions of DNA methylation: islands, start sites, gene bodies and beyond. Nature Reviews Genetics 13 484-492.

25. Kim S.J, Kelly W.K, Fu A, Haines K, et al (2011): Genomewide methylation analysis identifies involvement of TNF- $\alpha$ mediated cancer pathways in prostate cancer. Cancer Lett 302: 47-53.

26. Kohli R.M. and Zhang Y. (2013): TET enzymes, TDG and the dynamics of DNA demethylation. Nature 502 472-479.

27. Laurent L, Wong E, Li G., Huynh T, Tsirigos A, Ong C.T, et al. (2010): Dynamic changes in the human methylome during differentiation. Genome Research 20 320-331.

28. Lehmann U, Hasemeier B, Romermann D, Muller M, Langer F, et al (2007): Epigenetic inactivation of microRNA genes in mammary carcinoma. VerhDtschGesPathol 91: 214-220.

29. Li B, Carey M, Workman J.L, (2007): The role of chromatin during transcription. Cell 128; 4, 707-719.

30. Li S, Rong M, and Iacopetta B, (2006): DNA hypermethylation in breast cancer and its association with clinicopathological features. Cancer Lett 237: 272-280.

31. Li Y, Sun L, Zhang, Y, Wang D, Wang F, et al (2011):The histone modifications governing TFF1 transcription mediated by estrogen receptor. J. Biol. Chem. 286; 16, 13925-13936.

32. Luger K, Mäder A.W, Richmond R.K, Sargent, D.F, Richmond T.J, (1997): Crystalstructure of the nucleosome core particle at $2.8^{\circ}$ A resolution. Nature 389 (6648), 251-260.

33. Luger, K, Mäder, A.W, Richmond, R.K, Sargent, D.F, Richmond, T.J, (1997): Crystalstructure of the nucleosome core particle at $2.8^{\circ} \mathrm{A}$ resolution. Nature $389,251-260$.

34. Martignano F, Gurioli G, Salvi S, Calistri D, Costantini M, et al (2016): GSTP1 Methylation and Protein Expression in Prostate Cancer: Diagnostic Implications.Dis Markers.

35. Misteli, T. (2007): "Beyond the sequence: Cellular organization of genome function." Cell 128; 787-800.

36. Morgan H.D, Santos F, Green K, Dean W., and Reik W. (2005): Epigenetic reprogramming in mammals. Human Molecular Genetics 14 R47-R58.

37. Muller H. J. (1930): Types of visible variations induced by Xrays in Drosophila. J. Genet. 22: 299-334.

38. Nancy M. Bonini and Shelley L. Berger (2017):The Sustained Impact of Model Organisms- inGenetics and Epigenetics. Genetics, Vol. 205, 1-4.

39. Neri F, Rapelli S, Krepelova A, Incarnato D, Parlato , et al (2017): Intragenic DNA methylation prevents spurious transcription initiation. Nature 543; 72-77.

40. Pakneshan P., Szyf M, and Rabbani S.A.(2005): Hypomethylation of urokinase (UPA) promoter in breast and 
prostate cancer: prognostic and therapeutic implications. Curr Cancer Drug Targets 5: 471-488.

41. Parrella P, Poeta M.L, Gallo A.P, Prencipe M, Scintu M, et al, (2004): Non-random distribution of aberrant promoter methylation of cancer-related genes in sporadic breast tumors. Clin Cancer Res 10: 5349-5354.

42. Perria F. Longo F, Giuliano M, Sabbatino F, Faviaf G, et al (2017): Epigenetic control of gene expression: Potential implications forcancer treatment. Critical Reviews in Oncology/Hematology 111, 166-172.

43. Phe V, Cussenot O, and Roupret M. (2009): Interest of methylated genes as biomarkers in urothelial cell carcinomas of the urinary tract. BJU Int 104: 896-901.

44. Philip S, Xueqing Z, Hermann E, and Gaub K.(2013): Effects of cytosine hydroxymethylation on DNA strand separation. Schulten Biophysical Journal. 104; 208-215.

45. Pulukuri S.M, Patibandla S, Patel J, Estes N. and Rao J.S. (2007): Epigenetic inactivation of the tissue inhibitor of metalloproteinase-2 (TIMP-2) gene in human prostate tumors. Oncogene 26: 5229-5237.

46. Rauch T.A, Zhong X, Wu X. Wang M, Kernstine K.H, et al (2008):High-resolution mapping of DNA hypermethylation and hypomethylation in lung cancer. Proc Natl Acad Sci USA 105: 252-257.

47. Reibenwein J, Pils D, Horak P, Tomicek B, Goldner G, et al (2007): Promoter hypermethylation of GSTP1, AR, and 14-3$3 \sigma$ in serum of prostate cancer patients and its clinical relevance. Prostate 67: 427-432.

48. Rutherford A, (2015): "Beware the pseudo gene genies". The Guardian. 19 July 2015.

49. Seligson D.B, Horvath S, McBrianM.A.Mah V, Yu H, Tze S, et al (2009): Global levels of histone modifications predict prognosis in different cancers. Am J Pathol 174: 1619-1628.

50. Seligson D.B, Horvath S, Shi T, Yu H, Tze S, et al (2005): Global histone modification patterns predict risk of prostate cancer recurrence. Nature 435: 1262-1266.
Shi, Y. (2007): "Taking Epigenetics Center Stage.” Cell 128; 639-640.

52. Spurling C.C, Godman C.A, Noonan E.J, Rasmussen T.P, Rosenberg D.W.et al (2008): HDAC3 overexpression and colon cancer cell proliferation and differentiation. Mol Carcinog 47: 137-147.

53. Swift-Scanlan T, Vang R, Blackford A, Fackler M.J. and Sukumar S. (2011): Methylated genes in breast cancer: associations with clinical and histopathological features in a familial breast cancer cohort. Cancer Biol Ther 11: 853-865.

54. Tang W.W, Dietmann S, Irie N, Leitch H.G, Floros V.I, (2015) et al A unique gene regulatory network resets the human germline epigenome for development. Cell 161 1453-1467.

55. Tirado-Magallanes R., Rebbani K., Lim R., Pradhan S. and Benoukraf T. (2017) Whole genome DNA methylation: beyond genes silencing. Oncotarget 8 5629-5637.

56. Tokizane T, Shiina H, Igawa M, Enokida H, Urakami S,(2005): Cytochrome P450 1B1 is overexpressed and regulated by hypomethylation in prostate cancer. Clin Cancer Res 11: 57935801.

57. Venkatesh S., and Workman, J.L, (2015): Histone exchange, chromatin structure and the regulation of transcription. Nat. Rev. Mol. Cell Biol. 16; 178-189.

58. Voon H.P. and Gibbons R.J. (2016): Maintaining memory of silencing at imprinted differentially methylated regions. Cellular and Molecular Life Sciences: CMLS 73 1871-1879.

59. Wu H. and Zhang Y. (2014), Reversing DNA methylation: mechanisms, genomics, and biological functions. Cell 15645 68.

60. Yan L, Yang X, and Davidson N.E, (2001): Role of DNA methylation and histone acetylation in steroid receptor expression in breast cancer. J Mammary Gland Biol Neoplasia 6: 183-192.

61. Yin Q, Wang X, Fewell C, Cameron J, Zhu H, et al (2010): MicroRNA miR-155 inhibits bone morphogenetic protein (BMP) signaling and BMP-mediated Epstein-Barr virus reactivation. J Virol 84: 6318-6327.

51.

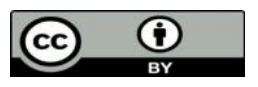

This work is licensed under Creative Commons Attribution 4.0 License

\section{To Submit Your Article Click Here: Submit Manuscript}

DOI: $10.31579 / 2690-8794 / 015$
Ready to submit your research? Choose Auctores and benefit from:

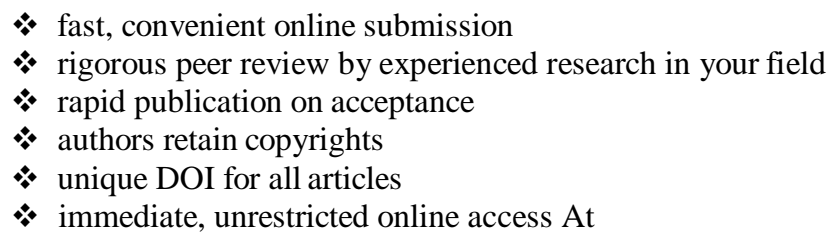

Auctores, research is always in progress.

Learn more www.auctoresonline.org/journals/clinical-medical-reviews- andreports 